\title{
SURVEY AND MAPPING OF RECENT ICE SHELF CHANGES AND LANDFAST SEA ICE GROWTH ALONG THE NORTH COAST OF ELLESMERE ISLAND, NWT, CANADA
}

\author{
by \\ M.O. Jeffries* \\ (Department of Geography, University of Calgary, Calgary, Alberta T2N 1N4, Canada) \\ and
}

H.V. Serson

(977 Stellyscross Road, Brentwood Bay, BC V0F 1A0, Canada)

\section{ABSTRACT}

Ground and aerial surveys along the north coast of Ellesmere Island confirm that a considerable area of shelf ice remains, although it is not as extensive as it once was due to periodic ice island calvings. However, the lost ice shelf is quickly replaced by landfast sea ice. The sea ice of ten persists for many years and thickens sufficiently to be considered as the restoration of former ice shelf. The landfast ice quickly assumes an undulating topography, similar to the ice shelves, the development of which is encouraged by melt water and wind action. Even under the present conditions of negative mass balance, the sea ice reaches considerable, undeformed thicknesses. The thick sea ice forming today could be the precursor of an expansion of the ice shelves. unique to this coast, grew as a result of thick sea-ice formation, which remained fast to the coast. The periodic disintegration of the ice shelves creates ice islands, which are generally carried with the pack ice towards the Beaufort Sea. With the likely exploration and development of offshore oil and gas reserves in the Beaufort Sea during the next decade, ice islands and thick sea ice floes could be a hazard to offshore installations. In order to understand this hazard, it is beneficial to have accurate information about the ice conditions on the north coast of Ellesmere Island. In $1980,1982,1983$, and 1984, we travelled extensively by snowmobile and aircraft along this coast, with the object of surveying and mapping recent ice-edge changes and the response of the landfast sea ice and ice shelves to these changes. This paper documents recent ice calvings and

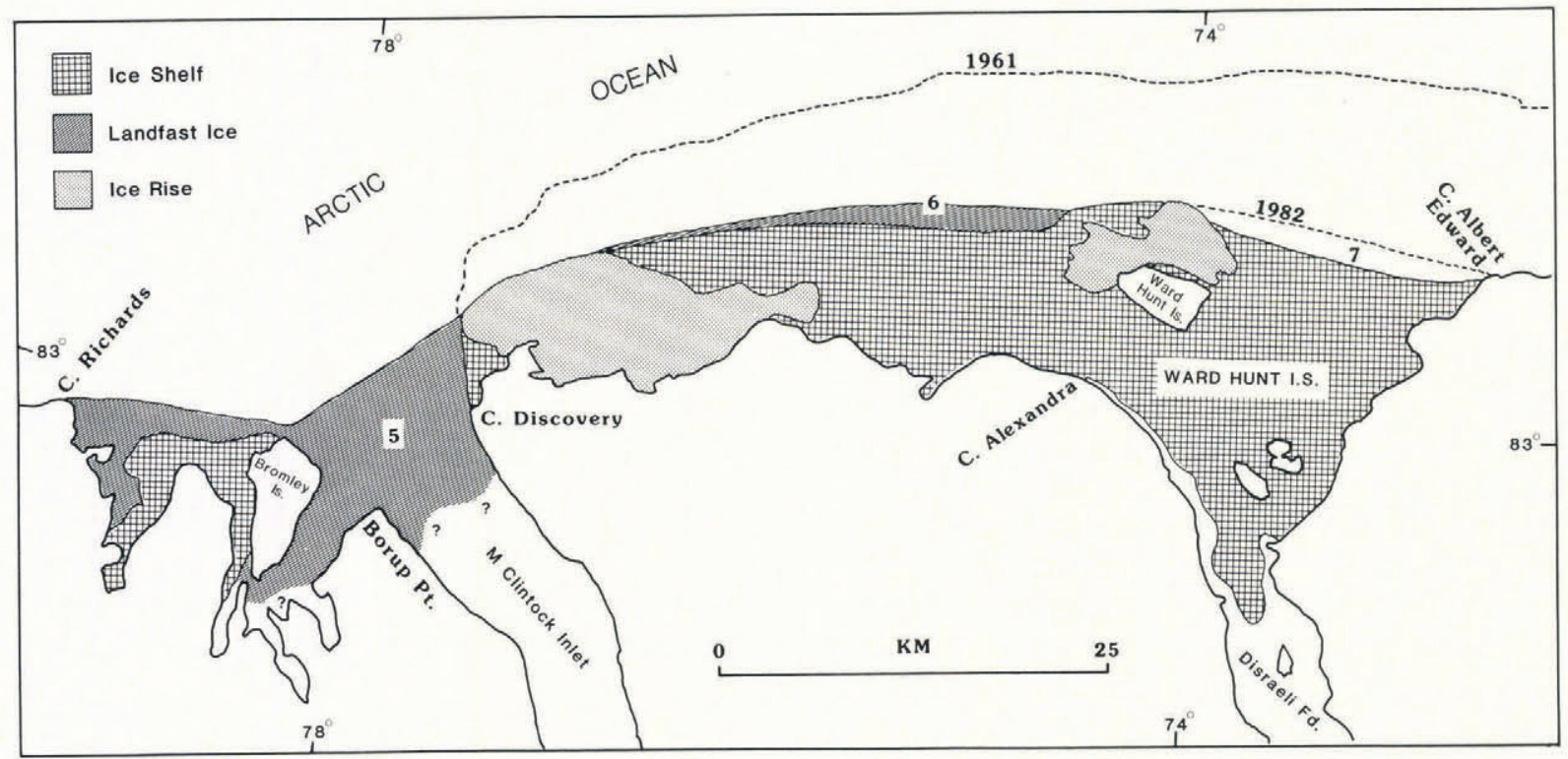

Fig.1. Map of northern Ellesmere Island, NWT. The largest remaining ice shelves (stippled areas) are shown, together with prominent capes, points, bays, inlets, and fiords on the north coast.

\section{INTRODUCTION}

The north coast of Ellesmere Island, from the mouth of Nansen Sound to Clements Markham Inlet (Fig.1), is fringed with ice, including first-year sea ice, multi-year sea ice and ice shelves. Many of the ice shelves, which are

* Now at: Geophysical Institute, University of Alaska, Fairbanks, Alaska, Alaska 99701, U.S.A. landfast ice growth and considers the relationship between the sea ice and the ice shelves, on the coastline between Yelverton Bay and C. Albert Edward.

\section{RECENT ICE EDGE CHANGES AND LANDFAST SEA} ICE GROWTH

1) Yelverton Bay

The most likely source of ice island T-3 is Yelverton Bay, where the former ice shelf disintegrated in about 1935 
(Hattersley-Smith, 1957). The bay is now almost entirely filled with $6 \mathrm{~m}$-thick landfast ice, within which a few, small, shelf-ice fragments are trapped. About $85 \mathrm{~km}^{2}$ of in situ ice shelf remains in this area: 1) $55 \mathrm{~km}^{2}$ in a bay east of Hanson Pt. (Fig.2); 2) $20 \mathrm{~km}^{2}$ at the west side of the bay (Fig.1); 3) $10 \mathrm{~km}^{2}$ in the south-west of the bay (not illustrated). The ice front generally extends in a direct line from C. Evans to Alert Point (Fig.1), although minor changes occur as a result of periodic calvings. The most recent change occurred in 1984, when about $30 \mathrm{~km}^{2}$ of ice broke away from Area 1 (Fig.2).

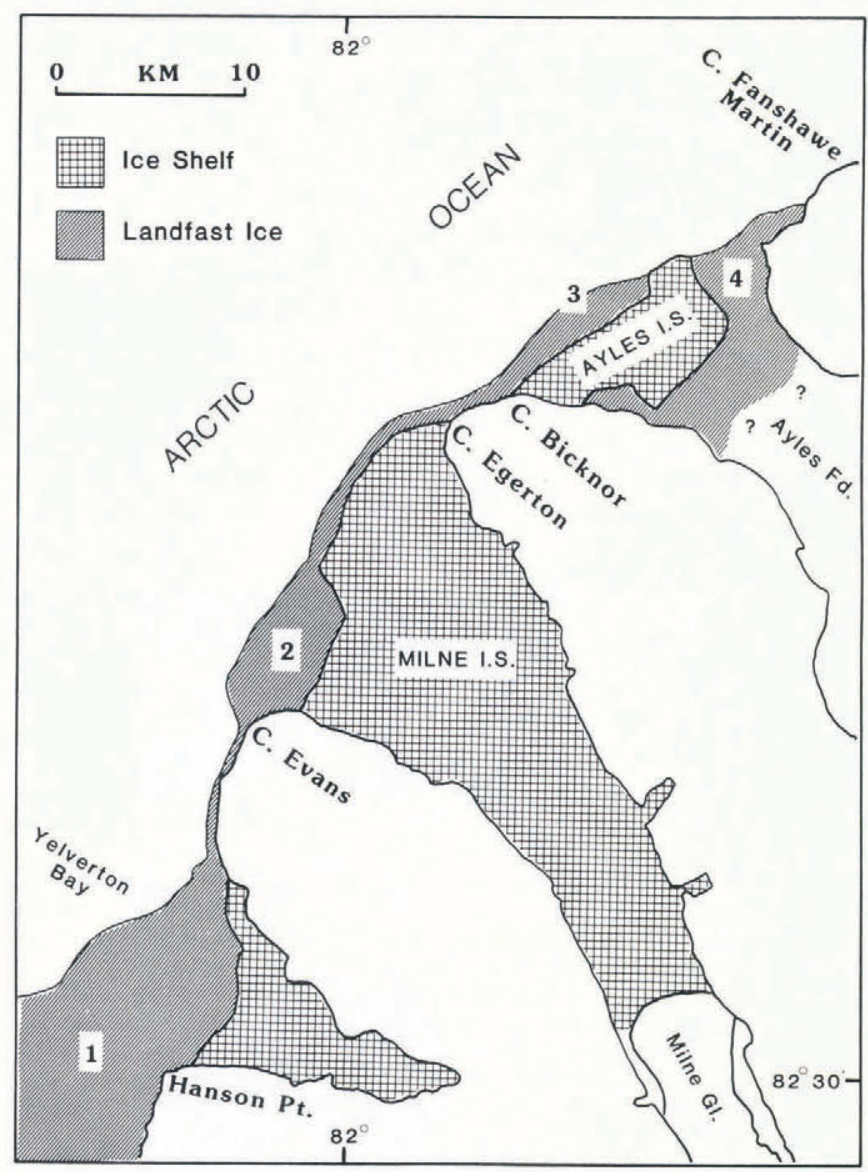

Fig.2. Map of ice shelves and landfast ice (Areas 1, 2, 3 and 4) between Yelverton Bay and C. Fanshawe Martin, 1984. The question marks in Ayles Ford indicate that the boundary between the landfast ice and the fiord ice is unknown.

\section{2) Cape Evans to Cape Egerton}

These capes mark the mouth of Milne Fiord, which contains Milne Ice Shelf (Figs.2 and 3). The latter has an area of about $300 \mathrm{~km}^{2}$ and is up to $100 \mathrm{~m}$ thick (Prager, 1983). In 1964, a small calving event, at the front of the ice shelf, created a $35 \mathrm{~km}^{2}$ ice island, with a volume of about $2.5 \mathrm{~km}^{3}$ (Jeffries, 1985). Since then, the area from which the ice island calved has been filled with an equivalent area of landfast ice that is up to $10 \mathrm{~km}$ thick (Area 2, Figs.2 and 3). North-east of Area 2, towards C. Egerton there is a narrow $(\sim 1 \mathrm{~km}$ wide) fringe of landfast ice along the front of the ice shelf.

3. Cape Egerton to Cape Fanshawe Martin

The narrow, landfast-ice fringe, along the north-east front of Milne Ice Shelf, continues past C. Egerton to C. Bicknor and along the front of Ayles Ice Shelf (Fig.2). At some time during the interval 1959-74, Ayles Ice Shelf moved about $5 \mathrm{~km}$ out of Ayles Fiord and away from the east shore (Figs.2 and 4). During the same period, a 15 $\mathrm{km}^{2}$ ice island, with a volume of $0.8 \mathrm{~km}^{3}$, calved from the ice shelf (Jeffries, In press).

Ayles Ice Shelf now has an area of about $55 \mathrm{~km}^{2}$ and the location from which the ice island broke away (Area 3, Figs.2 and 4) is filled with landfast ice. The movement of

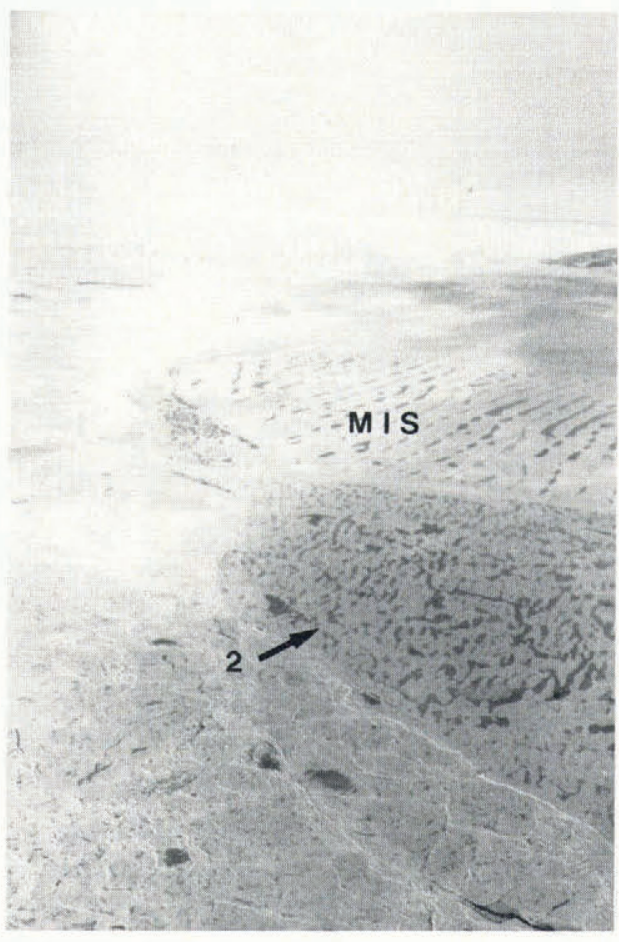

Fig.3. Oblique air photograph, looking across the mouth of Milne Fiord from C. Evans, July 1984. Note the difference in scale between the undulating topography of Milne Ice Shelf (MIS) and Area 2. (Source, MOJ.)

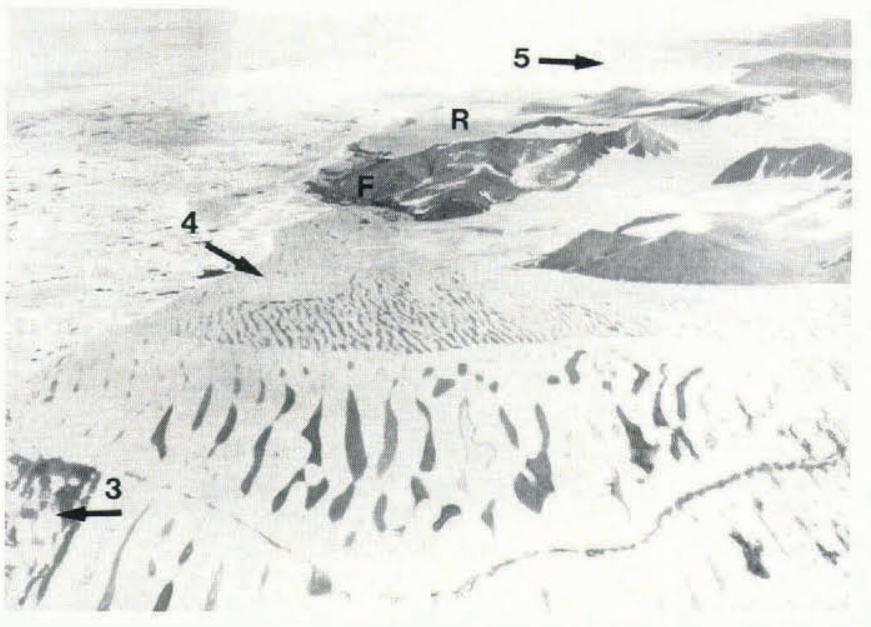

Fig.4. Oblique air photograph, looking across Ayles Ice Shelf (foreground) and Area 4 to $C$. Fanshawe Martin (F), C. Richards (R) and M'Clintock Inlet (5), July 1984. The ice in Areas 3 and 4 has a similar topography to that in Area 2 (Fig.3) and contrasts with the larger-scale undulations on the ice shelf. (Source MOJ.)

the ice shelf away from the shore created a space (Area 4, Figs.2 and 4), which now contains landfast ice, together with fragments of shelf ice. The landfast ice extends to the rear of the ice shelf, but it is not known how far. Further into the fiord, the ice cover is non-saline and contains numerous small icebergs, derived from a disintegrating ice tongue.

\section{Cape Fanshawe Martin to Cape Richards}

The foreshore at C. Fanshawe Martin consists of a low-lying area of boulders and rock rubble, interlaced with frozen ponds, which flood at high tide, and extends for about $7 \mathrm{~km}$ as far as C. Richards (Figs.2, 4 and 5) (Serson, 1983). In 1980, $10 \mathrm{~m}$-thick, landfast ice extended about $1 \mathrm{~km}$ seaward from C. Fanshawe Martin, but, in 1984 , a $1 \mathrm{~km}$ by $3 \mathrm{~km}$ piece of ice had broken away (Fig.4). 


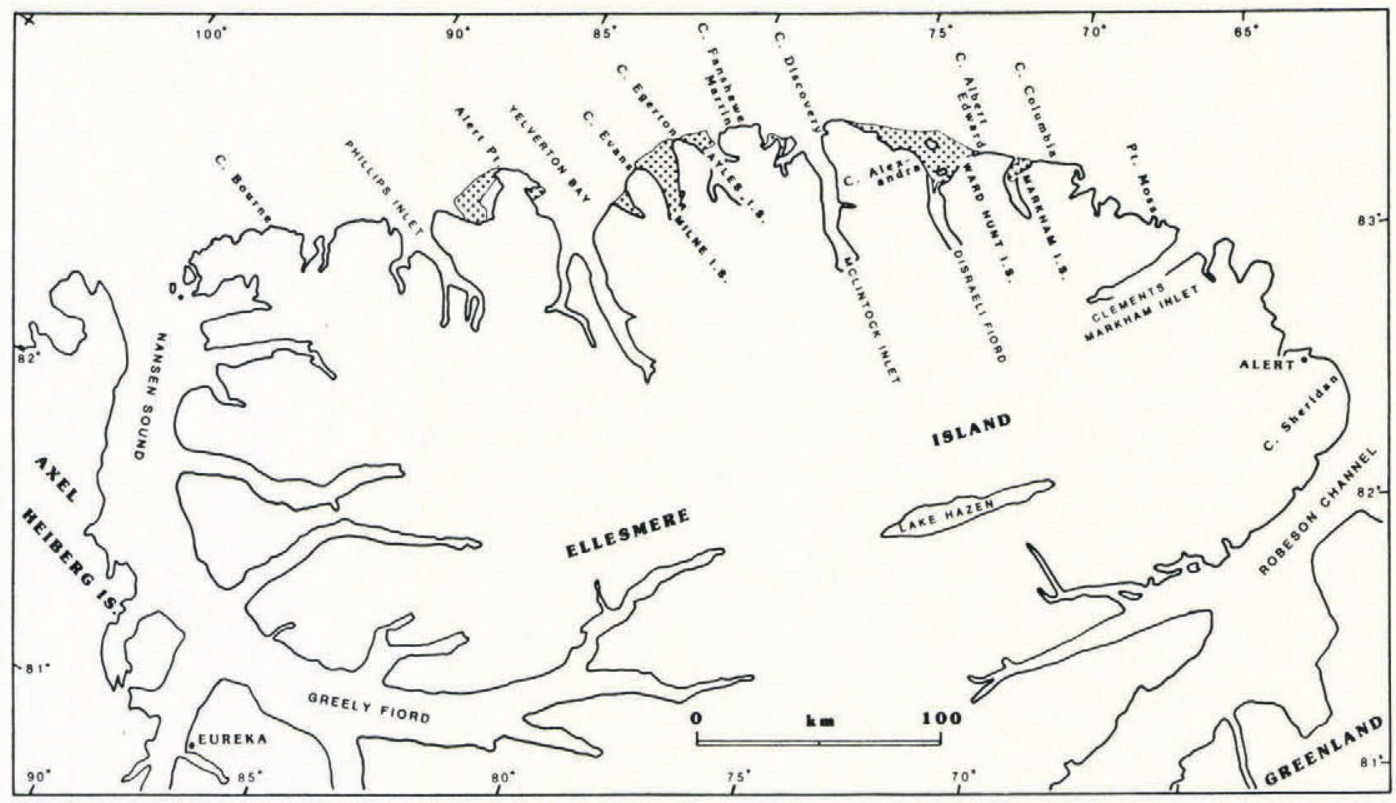

Fig.5. Map of ice shelves and landfast ice (Areas 5, 6 and 7), between C. Richards and C. Albert Edward, 1984. The question marks in M'Clintock Inlet indicate that the boundary between the landfast ice and the fiord ice is unknown.

\section{Cape Richards to Cape Discovery}

In June 1962, the outer $10 \mathrm{~km}$ of $\mathrm{M}^{\prime}$ Clintock Inlet (Figs.4 and 5) were covered by the unbroken M'Clintock Ice Shelf, which had disintegrated by April 1966 (HattersleySmith 1967). Between C. Richards and C. Discovery, there now exist only two small areas of in situ shelf ice: 1) 35 $\mathrm{km}^{2}$, west of Bromley Island; 2) $6 \mathrm{~km}^{2}$, in a small bay, north of C. Discovery (Fig.5). The mouth of $\mathrm{M}^{\prime}$ Clintock Inlet is now filled with $10 \mathrm{~m}$-thick landfast ice (Area 5 , Fig.5). Numerous fragments of old shelf ice, with rocks and boulders on their surfaces, are trapped within the sea ice. South of Borup Point (Fig.5), the sea ice merges with the fiord ice, which also contains fragments of old shelf ice. The position of the ice front, between the capes, varies due to occasional small calvings. In 1982, the landfast ice extended up to $5 \mathrm{~km}$ north of Bromley Island, but a calving of up to $50 \mathrm{~km}^{2}$ of ice, during the interval $1982-83$, left the ice front as illustrated in Figure 5 .

6. Cape Discovery to Cape Albert Edward

In August 1961 (Fig.5), Ward Hunt Ice Shelf covered an area of over $1000 \mathrm{~km}^{2}$ and had a volume of 38 to 44 $\mathrm{km}^{3}$. Between August 1961 and April 1962, a massive calving caused an ice loss of almost $600 \mathrm{~km}^{2}$, with a volume of 18 to $24 \mathrm{~km}^{3}$ (Hattersley-Smith, 1963). By 1980 , it is estimated that about $75 \mathrm{~km}$ of ice shelf had regrown, as a result of sea-ice accretion at its front (e.g. Area 6, Figs.5 and 6).

The ice-shelf front remained quite stable until the 1980s. During the interval 1980-82, approximately $40 \mathrm{~km}^{2}$ of shelf ice and fast ice grounded and/or calved at the extreme west end of the ice shelf, immediately north of the C. Discovery Ice Rise (Fig.5) (Jeffries, 1982). In 1982-83, up to $40 \mathrm{~km}^{2}$ of shelf ice and fast ice calved from the ice-shelf front, between C. Albert Edward and the Ward Hunt Ice Rise (Area 7, Figs.5 and 6) (Jeffries and Serson, 1983). In spring 1984, Ward Hunt Ice Shelf covered an area of about $440 \mathrm{~km}^{2}$ and had an estimated volume of 20 $\mathrm{km}^{3}$.

Of the sea ice which accreted after 1963, only the 45 $\mathrm{km}^{2}$ Area 6 remains (Figs.5 and 6). However, in spring 1984 , small areas of second-year sea ice had already accreted, west of C. Albert Edward (Fig.5).

\section{DISCUSSION}

Over the past 50 years, there has been a considerable loss of shelf ice from the north coast of Ellesmere Island, the greatest losses having occurred at Yelverton Bay, M'Clintock Inlet, and Ward Hunt Ice Shelf. Ice calvings occur every third or fourth year, at apparently random intervals (Sackinger and others, 1985), but it is difficult to

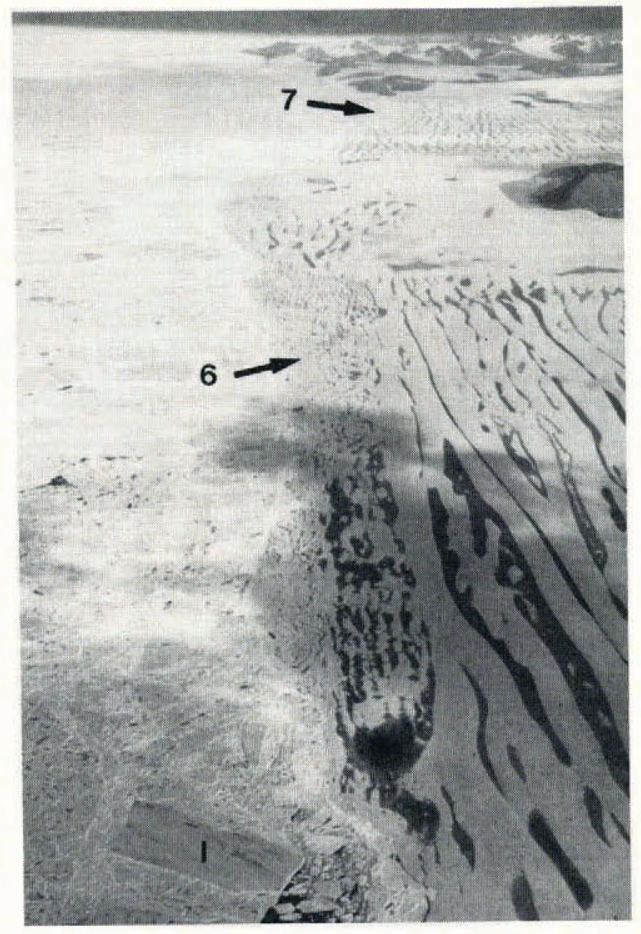

Fig.6. Oblique air photograph, looking east along the front of Ward Hunt Ice Shelf, July 1984. The landfast ice of Area 6 has an undulating topography, similar to that of Areas 2, 3 and 4 , but on a much smaller scale than on the ice shelf. Note the small ice island (1) at lower left. (Source, MOJ.)

predict the timing, location, and magnitude of calvings. Furthermore, although some calvings have been attributed to tidal and seismic events (Holdsworth, 1971), little is known about the causes of ice-shelf disintegration. From Yelverton Bay to C. Albert Edward (Fig.1), there are now about 920 $\mathrm{km}^{2}$ of in situ ice shelf, $80 \%$ of which includes the Ward Hunt and Milne Ice Shelves. The same stretch of coast includes about $901 \mathrm{~km}^{2}$ of landfast ice, most of which is found in Yelverton Bay and $\mathrm{M}^{\prime}$ Clintock Inlet. The landfast ice has grown since each calving and is evidence that the ice shelves are quickly replaced. In cases such as Area 2 (Figs.2 and 3), Area 3 (Fig.2), and Area 6 (Figs.5 and 6), 
where landfast ice has accreted at the front of the ice shelves, the ice growth could be considered as ice shelf regeneration.

In Figures 3, 4, and 6 , it can be seen that the landfast ice, like the ice shelves, has a similar, but smaller-scale, undulating topography, parallel to the coastline and prevailing winds. On the sea ice, the ridge tops are approximately $60 \mathrm{~m}$ apart and the troughs up to $1 \mathrm{~m}$ deep. In contrast, the ice-shelf ridges vary from $200 \mathrm{~m}$ to $300 \mathrm{~m}$ apart and the troughs are as much as $7.5 \mathrm{~m}$ deep. The origin of the ice-shelf rolls is unclear, but could have been due to pack-ice pressure and pressure-ridge formation, during early, sea-ice growth (Hattersley-Smith, 1957; Lister, 1962). Subsequently, as the ice thickened, the rolls deepened and became oriented parallel to the prevailing winds, which drove melt water along the troughs (Hattersley-Smith, 1957; Crary, 1960; Lister, 1962). At the present time, there is an adequate supply of melt water, due to the relatively warm summers and consequent negative, surface mass balance, which accumulates in depressions as melt ponds. Some areas of the landfast ice are mechanically deformed and this would account for the ridges and troughs. However, most of the ice is undeformed and, in this case, the ridges and troughs probably develop as a result of wind action and melt-pond coalescence. As the ice thickens and ages, the ridges and troughs develop a sub-parallel pattern which is evident in Figures 3, 4, and 6 .

The undeformed, landfast ice varies from $2 \mathrm{~m}$ to $10 \mathrm{~m}$ in thickness, with most of the ice being at the thicker end of the range. Undeformed, multi-year ice in the Arctic Ocean commonly has a steady-state thickness of $2.5 \mathrm{~m}$ to 5 m (Maykut and Untersteiner, 1971), but it has been shown that undeformed sea ice can reach thicknesses of at last $12 \mathrm{~m}$, under present climatic conditions (Walker and Wadhams, 1979). Clearly, this is the case with the landfast ice common to the north coast of Ellesmere Island, which, as Hattersley-Smith (1972) suggested, grows up to the point where it can be regarded as incipient ice shelf.

The salinity and oxygen-18 composition of present landfast ice is evidence of a strong, fresh-water, run-off influence, which leads to fresh, brackish, or saline ice accretion, according to the prevailing meteorological and oceanographic conditions (Jeffries, 1985). Present landfast-ice growth has been likened to the brackish, basement ice, described by Lyons and others (1971), and is believed to have preceded the original, basement, ice growth (Jeffries, 1985). The latter sea ice forms the core of Ward Hunt Ice Shelf, west of Ward Hunt Island, and is evidence of thick, sea-ice growth, which occurred about 4000 years ago, when the climate was cooler, with much less run-off than at present (Jeffries and Krouse, in press). A climatic cooling trend, continuing to the end of the present century, has been predicted by Johnsen et al. (1970) and Hibler and Langway (1977). The response of the ice shelves to this trend might be further expansion, as a result of lateral fast-ice accretion, which will increasingly resemble the original, basement ice. If this is so, the ice shelves might be expected to thicken and become more extensive, in the decades to come. Although the ice shelves might expand, it is likely that calvings will continue, creating large ice features, either of shelf ice or thick sea ice. Thus, it is suggested that Ayles Ice Shelf, already dislodged from its former, more secure position in Ayles Fiord, could break away completely and become an ice island.

\section{ACKNOWLEDGEMENTS}

This work was undertaken whilst $M O$ Jeffries was a graduate student at The University of Calgary. Fieldwork was made possible through the logisitic support of The Polar Continental Shelf Project (G. D. Hobson, Director) and financial support of the following; Dome Petroleum, Gulf Canada Resources, Petro Canada, Defence Research Establishment Pacific Arctic Institute of N. America and The University of Calgary. All assistance is gratefully acknowledged.

\section{REFERENCES}

Crary A P 1960 Arctic ice island and ice shelf studies. Part

II. $\operatorname{Arctic}$ 13(1): $32-50$
Hattersley-Smith G 1957[a] The Ellesmere Ice Shelf and the ice islands. Canadian Geographer 9: $65-70$

Hattersley-Smith G 1957[b] The rolls on the Ellesmere Ice Shelf. Arctic 10(1): 32-44

Hattersley-Smith G 1963 The Ward Hunt Ice Shelf: recent changes of the ice front. Journal of Glaciology 4(34): $415-424$

Hattersley-Smith G 1967 Note on ice shelves off the north coast of Ellesmere Island. Arctic Circular 17(1), 1965-66: 13-14

Hattersley-Smith G 1972 Climatic change and related problems in northern Ellesmere Island, N.W.T., Canada. In Vasari $\mathrm{Y}$, Hyvärinen $\mathrm{H}$, Hicks $\mathrm{S}$ (eds) Climatic changes in Arctic areas during the last ten-thousand years. Oulu, University of Oulu: 137-148 (Acta Universitatis Ouluensis. Ser A. Scientiae Rerum Naturalium 3. Geologica 1)

Hibler W D III, Langway C C Jr 1977 Ice core stratigraphy as a climatic indicator. In Dunbar M J (ed) Polar oceans. Proceedings of the Polar Oceans Conference...Montreal, May 1974. Calgary, Arctic Institute of North America: 589-601

Holdsworth G 1971 Calving from Ward-Hunt Ice Shelf, 1961-1962. Canadian Journal of Earth Sciences 8(2): 299-305

Jeffries MI O 1982 The Ward Hunt Ice Shelf, spring 1982. Arctic 35(4): 542-544

Jeffries $M O$ In press Ice island calvings and ice shelf changes, Milne Ice Shelf and Ayles Ice Shelf, Ellesmere Island, NWT. Arctic

Jeffries M O Unpublished Physical, chemical and isotopic investigations of Ward Ilunt Ice Shelf and Milne Ice Shelf, Ellesmere Island, NWT. (PhD thesis, University of Calgary, Alberta, Canada, 1985)

Jeffries $M O$, Krouse $H R$ In press Arctic ice shelf growth, fiord oceanography and climate. Symposium on Climate and Palaeoclimate of Lakes, Rivers and Glaciers. Igls near Innsbruck, Austria, 4-7 June, 1984. Zeitschrift für Gletscherkunde und Glazialgeologie

Jeffries M O, Serson II 1983 Recent changes at the front of Ward Hunt Ice Shelf, Ellesmere Island, N.W.T. Arctic 36(3): $289-290$

Johnsen S J, Dansgaard W, Clausen HI B, Langway C C Jr 1970 Climatic oscillations 1200-2000 AD. Nature 227(5257): $482-483$

Lister H 1962 Mass balance studies on the Ellesmere Ice Shelf. Journal of Glaciology 4(33): 298-299

Lyons J B, Savin S M, Tamburi A J 1971 Basement ice, Ward Hunt Ice Shelf, Ellesmere Island, Canada. Journal of Glaciology 10(58): 93-100

Maykut G A, Untersteiner N 1971 Some results from a time-dependent thermodynamic model of sea ice. Journal of Geophysical Research 76(6): 1550-1575

Prager B T Unpublished Digital signal processing of UHF radio-echo sounding data from northern Ellesmere Island. (MSc thesis, University of British Columbia, Vancouver, Canada, 1983)

Sackinger W M, Shoemaker H D, Serson H, Jeffries M O, Yan M 1985 Ice islands as hazards to Arctic offshore production structures. Proceedings of the 17th Annual Offshore Technology Conference, Houston, Texas, 6-9 May 1985: 399-408

Serson H V 1983 Ice conditions off the north coast of Ellesmere Island, spring 1980. Canada Defence Research Establishment Pacific. Technical Memorandum 83-8

Walker E R, Wadhams P 1979 Thick sea-ice floes. Arctic 32(2): $140-147$ 